\title{
Działalność Towarzystwa Miłośników Torunia w okresie od 26 maja 2017 r. do 24 maja 2018 r.
}

Katarzyna Tomkowiak

Toruń

\section{Członkowie Towarzystwa}

Towarzystwo Miłośników Torunia liczy obecnie 139 członków, z czego w kole śródmiejskim 111 osób, w kole podgórskim 13, a w sekcji krótkofalowców 15.

W okresie sprawozdawczym do Towarzystwa wstąpiło sześć osób: Krzysztof Czarnecki, Rafał Maszewski, Waldemar Rutkowski - sekcja krótkofalowców, Stanisław Wroński, Włodzimierz Deczyński, Krzysztof Dominikowski. Z grona członków i działaczy Towarzystwa odeszli m. in.:

- 13 grudnia 2017 r. Stefan Kościelecki, 84 lata, prof. WSP UMK, artysta malarz, członek słynnej Grupy Toruńskiej, twórca „Współczesnej koncepcji wychowania plastycznego", inicjator powstania Galerii i Ośrodka Twórczości Plastycznej Dziecka oraz pierwszy kierownik Studenckiego Klubu Pracy Twórczej „Od Nowa” w Toruniu; były członek Zarządu ToMiTo;

- 6 lutego 2018 r. Małgorzata Dolecka, członkini sekcji krótkofalowców;

- 11 marca 2018 r. Gerard Dyduch, 64 lata, członek sekcji krótkofalowców;

- 11 maja 2018 r. Karol Bafia, 86 lat, długoletni i aktywny członek ToMiTo, wielokrotny uczestnik i laureat nagród w konkursie „Toruń w kwiatach”.

\section{Walne Zebranie i władze Towarzystwa}

Na Walnym Zebraniu Sprawozdawczo-Wyborczym w dniu 25 maja 2017 r. wybrano nowe władze Towarzystwa: Zarząd tworzą: prezes i redaktor Toruńskiego Słownika Biograficznego Krzysztof Mikulski, wiceprezesi - Piotr Oliński, Michał Targowski, sekretarz - Katarzyna Tomkowiak, skarbnik - Piotr Birecki, przewodniczący sekcji historycznej - Krzysztof Kopiński, przewod- 
nicząca Koła Podgórz - Ludmiła Stadnicka-Kozłowska, przewodniczący sekcji łączności z mediami - Wiesław Nowosad, przewodniczący sekcji do spraw wizerunku miasta - Roman Spandowski, przewodniczący sekcji krótkofalowców - Mariusz Thomas, przewodnicząca sekcji wydawniczej i redaktor Rocznika Toruńskiego - Agnieszka Zielińska, członkowie Zarządu: Cecylia Iwaniszewska, Jarosław Kłaczkow, Kamila Maj, Sławomir Pułkownik, Andrzej Szmak, Jolanta Wasiewska.

Komisję Rewizyjną Towarzystwa tworzą: przewodnicząca - Stefania Sieracka, członkowie: Jacek Tylicki, Andrzej Warot.

W okresie sprawozdawczym Zarząd zbierał się trzykrotnie na zebraniach protokołowanych (w tym jedno posiedzenie miało charakter okolicznościowy - noworoczny), a Prezydium spotykało się częściej w celu załatwiania bieżących spraw. Komisja Rewizyjna zebrała się dnia 25 kwietnia 2018 r. dla oceny działalności Zarządu.

Skład Prezydium i Zarządu Towarzystwa nie uległ zmianie w okresie sprawozdawczym.

Biurem Towarzystwa kieruje pracująca na pół etatu Joanna Danuta Horyza, która prowadzi również księgowość. Biuro mieści się w budynku przy ul. Podmurnej 60, należącym do Gminy Miasta Toruń. Towarzystwo użytkuje tam pomieszczenie biurowe na I piętrze o powierzchni $21,35 \mathrm{~m}^{2}$. Ryczałtowa opłata miesięczna za media wynosi $350 \mathrm{zł}$. Biblioteka Towarzystwa, licząca obecnie 685 tomów, oraz wszystkie wydawnictwa znajdują się w tym samym pomieszczeniu biurowym.

Witryną internetową Towarzystwa zajmują się Wiesław Nowosad i Joanna Horyza. Strona dostępna jest pod adresem: www.tomito.cba.pl.

\section{Działalność Towarzystwa}

Od wielu lat działalność Towarzystwa Miłośników Torunia obejmuje następujące dziedziny: współdziałanie $\mathrm{z}$ władzami miasta, popularyzowanie wiedzy o Toruniu oraz wydawanie publikacji związanych z dziejami Torunia.

Współdziałanie z władzami miasta

Do corocznego konkursu „Toruń w kwiatach” zgłoszono 81 balkonów i ogródków przydomowych, które poddano ocenie. Komisja konkursowa przyznała 22 miejsca pierwsze, 40 drugich, 12 trzecich oraz jedno wyróżnienie, trzy osoby otrzymały nagrody prezydenta miasta - statuetki „Flisaka”. Komisja działała w składzie: Elżbieta Thomas - przewodnicząca, Ludmiła Stadnicka-Kozłowska, Alina Dauksza-Wiśniewska (fotograf) - członkowie 
z ramienia ToMiTo - oraz ogrodniczki Wiesława Dudzińska i Lilia Kowalska. Członkowie komisji dokonali oceny zgłoszonych obiektów w dniach od 6 do 20 lipca 2017 r. Zakończenie konkursu, które odbyło się 13 października 2017 r. w Sali Mieszczańskiej Ratusza Staromiejskiego, było wspólnym podsumowaniem dwóch konkursów: „Toruń w kwiatach 2017” oraz konkursu ogłoszonego przez prezydenta miasta „Toruń Ogrodem”. W trakcie ceremonii, którą prowadził wiceprezes ToMiTo Michał Targowski, a nagrody wręczali prezydent Torunia Michał Zaleski wraz z Piotrem Olińskim, można było oglądać fotografie nagrodzonych pięknych balkonów i roślinności w ogrodach wykonane przez Alinę Daukszę-Wiśniewską. Prezydent Torunia podziękował uczestnikom konkursu za: „pracowitość w staraniach nad ukwieceniem balkonów i ogrodów. Toruń jest pięknym i zielonym miastem [...] piękno tkwi w różnorodności kwiatów przez Was uprawianych, hodowanych".

Wraz z Urzędem Miasta Torunia kontynuowano prace nad przeglądem i rejestracją mogił osób zasłużonych dla Torunia. W dniu 21 września 2017 r. odbyło się spotkanie, podczas którego dokonano wyboru obiektów do renowacji. Komisja w składzie: prof. Jadwiga Łukaszewicz, dr Karolina Witkowska z Zakładu Konserwacji Detali Architektonicznych UMK, Joanna Cywińska-Raczkowska i Małgorzata Litwin z Wydziału Komunikacji Społecznej i Informacji Urzędu Miasta oraz dr Arkadiusz Kierys, kierujący pracami renowacyjnymi z ramienia ToMiTo, a także dr Cecylia Iwaniszewska, członek zarządu ToMiTo, zaproponowała wykonanie następujących prac:

- renowację krzyża nagrobnego z inskrypcją z 1854 r. kpt. Antoniego Ignacego Żernickiego (1788-1836),

- dokończenie prac przy nagrobku rodziny Raapke; konieczne będzie odwrócenie położenia jednego z bloków kamiennych podtrzymujących konstrukcję nagrobka,

- przywrócenie ogrodzenia przy odnowionym kilka lat temu nagrobku rodziny Kazimiery Karnickiej-Biuszel (odrestaurowanym w 2012).

W trakcie 15. kwesty na cmentarzu św. Jerzego przy ul. Gałczyńskiego Toruniu, w dniu 1 listopada 2017 r., wzięło udział 40 osób, także członkowie Zarządu ToMiTo i Bractwa Kurkowego, członkowie Zarządu Miasta wraz z prezydentem Michałem Zaleskim i wiceprezydentami Zbigniewem Fiderewiczem, Andrzejem Rakowiczem, Zbigniewem Rasielewskim oraz z przewodniczącym Rady Miasta Marcinem Czyżniewskim. Kwestowali przedstawiciele władz samorządowych, m.in. sekretarz województwa Marek Smoczyk, a także dziennikarze, sportowcy, marynarze z patronackiego okrętu ORP Toruń. Nie zabrakło przedstawicieli nauki i kultury z rektorem UMK prof. Andrzejem Tretynem. Wśród kwestujących znaleźli się też: Anna Bogłowska, 
Magdalena Cynk, Arkadiusz Myrcha, Wojciech Polak, Stanisław Rakowicz, Przemysław Termiński, Karol Maria Wojtasik, Dorota Zawacka-Wakarecy. Na renowację zniszczonych nagrobków na cmentarzu zebrano 18 133,55 zł. Ofiarodawcom wręczano kolorowy folder z opisem odnowionych nagrobków. $\mathrm{O}$ tradycjach toruńskiego kwestowania, zainicjowanych i przeprowadzanych przez członków ToMiTo, mówiła C. Iwaniszewska, członek Zarządu Towarzystwa, w „Zbliżeniach” TV Bydgoszcz w dniu 31 października 2017 r. Podkreśliła, że coroczne kwesty to „początek lekcji historii” i ToMiTo pragnie „uczyć historii poprzez kwesty”.

Z udziałem władz miejskich 2 listopada 2017 r. odbyło się także zebranie w sprawach dotyczących próby inwentaryzacji mogił zasłużonych torunian. ToMiTo reprezentowali: K. Mikulski, M. Targowski, C. Iwaniszewska, A. Szmak. Na kolejnym spotkaniu, 30 listopada 2017 r., dokonano odbioru odnowionego nagrobka z kwatery rodziny Araczewskich, toruńskich handlowców i rzemieślników. Obecni byli prof. Jadwiga Łukaszewicz, dr Karolina Witkowska, mgr Anna Kałucka z biura konserwatora zabytków oraz dr Arkadiusz Kierys i dr Cecylia Iwaniszewska.

Członkowie Zarządu Krzysztof Kopiński i Cecylia Iwaniszewska współdziałali z Komisją Polityki Społecznej i Zdrowia oraz Kultury i Promocji Rady Miasta w sprawach dotyczących nazewnictwa ulic i placów. Do ostatnich prac dołączyła Katarzyna Tomkowiak.

Dnia 11 kwietnia 2017 r. prezydent miasta Torunia zorganizował spotkanie dotyczące aktualizacji „Strategii Rozwoju Miasta Torunia do 2023 roku”. W spotkaniu wziął udział Michał Targowski - wiceprezes ToMiTo, który tę współpracę w imieniu Towarzystwa kontynuował w 2018 r. Za swój wkład w opracowywanie „Strategii miasta do roku 2020 z uwzględnieniem perspektywy rozwoju do 2028 r." otrzymał podziękowanie od prezydenta miasta Torunia 5 kwietnia 2018 r. W dokumencie zaznaczono, że przedstawiciele toruńskich środowisk społecznych, ich opinie i wnioski nadały „Strategii miasta” profesjonalny charakter.

W okresie sprawozdawczym Towarzystwo wspierało wiele inicjatyw lokalnych, m.in.:

- przekazano wydawnictwa ToMiTo na nagrody w Wojewódzkim Konkursie Katarzynkowym, organizowanym dla dzieci przez Oddział Przewodnicki PTTK, a członkowie ToMiTo wzięli udział w uroczystości wręczenia nagród w dniu 8 grudnia 2017 r. w auli I LO w Toruniu,

- przekazano wydawnictwa ToMiTo na nagrody dla dzieci w konkursie mikołajkowym, organizowanym przez Koło ToMiTo Podgórz oraz na nagrody 
dla uczestników konkursu XVIII edycji Miejskiego Konkursu Historycznego „Dzieje Torunia”,

- Towarzystwo współpracowało z Oddziałem Przewodnickim PTTK w Toruniu, m.in. 17 listopada 2017 r. M. Targowski i C. Iwaniszewska brali udział w obchodach 65. rocznicy powstania Oddziału, a 8 grudnia tego roku C. Iwaniszewska uczestniczyła w zakończeniu konkursu wojewódzkiego dla młodzieży, zorganizowanego przez Oddział Przewodnicki,

- Zarząd Towarzystwa 21 grudnia 2017 r. wyraził całkowite poparcie dla wniosku o przyznanie tytułu Honorowego Obywatela Miasta Torunia profesorowi Stanisławowi Salmonowiczowi.

\section{Popularyzowanie wiedzy o Toruniu}

Przeprowadzono XXVI konkurs na najlepsze prace magisterskie i dyplomowe poświęcone Toruniowi. Uroczyste zakończenie odbyło się 19 marca 2018 r. w Sali Rady Ratusza Staromiejskiego, w którym uczestniczył wiceprezydent Torunia Andrzej Rakowicz. W ramach konkursu nagrodzono osiem prac. Komisja pracowała w składzie: przewodniczący - Krzysztof Kopiński i członkowie - Agnieszka Zielińska i Piotr Birecki. Po raz pierwszy konkurs miał charakter ogólnopolski. Przyznano następujące nagrody i wyróżnienia:

- z zakresu archiwistyki:

I nagroda - Bartłomiej Konopa za pracę magisterską „Źródła do dziejów muzyki w Toruniu do 1920 r. - katalog archiwaliów przechowywanych w Archiwum Państwowym w Toruniu",

II nagroda - Justyna Dominika Kęska za pracę magisterską „Dzieje Archiwum Toruńskiego w latach 1945-1989",

- z zakresu archeologii:

II nagroda - Jakub Rychlik za pracę magisterską „Analiza nawarstwień kulturowych po południowej stronie kościoła św. Jakuba w Toruniu (badania w latach 2008-2015)",

- z zakresu kulturoznawstwa:

wyróżnienie - Łukasz Radoliński za pracę licencjacką „Reklama w przestrzeni miejskiej. Przykład Torunia",

- z zakresu finansów i rachunkowości:

wyróżnienie - Magdalena Bartulewicz za pracę licencjacką „Analiza wydatków gminy w kontekście równowagi budżetowej na przykładzie Gminy Miasta Torun w latach 2011-2015",

- z zakresu inżynierii lądowej i geodezji:

I nagroda - Magdalena Węgrzyn za pracę dyplomową inżynierską „Opracowanie aplikacji turystycznej z wykorzystaniem rozszerzonej rzeczywistości”, 
- z zakresu nauk o ziemi:

I nagroda - Anna Łątkowska za pracę magisterską „Stan i struktura osiedli grodzonych w Toruniu",

wyróżnienie - Leszek Dąbrowski za pracę licencjacką „Mapowanie sektorów kreatywnych w przestrzeni toruńskiej Starówki dla projektu GEN-Y City”,

- z zakresu architektury i sztuki:

II nagroda - Daria Orłowska za pracę magisterską „Kontynuowanie programu $\mathrm{i}$ jego przestrzennej interpretacji dla muzeum tańca $\mathrm{w}$ miejskiej zabudowie Torunia",

II nagroda - Tomasz Ziemkiewicz za pracę licencjacką „Problematyka konserwatorska architektury modernistycznej na przykładzie dawnego gmachu Starostwa Krajowego Pomorskiego w Toruniu",

III nagroda - Anna Hildebrandt-Fijorek za pracę magisterską „Zespół zabudowy mieszkaniowo-usługowej na terenie dawnej rzeźni miejskiej w Toruniu”,

- z zakresu historii wojskowej:

wyróżnienie - Paweł Pilarski za pracę licencjacką „Wpływ poligonu artyleryjskiego na życie Torunia w latach 1867-1939 w świetle lokalnej prasy".

O konkursie, jego laureatach i zmianie formuły - uwzględnieniu prac $\mathrm{z}$ terenu całej Polski w rywalizacji o laur najlepszych prac o Toruniu - mówił w wywiadzie dla TV Toruń prezes ToMiTo K. Mikulski.

W dniu 14 października 2017 r. odbyła się konferencja naukowa wraz z wystawą z okazji 500-lecia reformacji. Prócz Towarzystwa Miłośników Torunia organizatorami przedsięwzięcia „Toruń Miastem Wielu Wyznań” były: Instytut Historii i Archiwistyki UMK, Diecezja Pomorsko-Wielkopolska Kościoła Ewangelicko-Augsburskiego oraz Parafia Ewangelicko-Augsburska w Toruniu. W programie konferencji znalazły się cztery referaty. Swe wystąpienia zaprezentowali kolejno: bp dr hab. Marcin Hintz, prof. ChAT (Duchowość $i$ teologia ewangelicka XVII wieku ze szczególnym uwzględnieniem Prus), toruński historyk prof. dr hab. Waldemar Rozynkowski - dyrektor IHiA UMK, diakon rzymskokatolicki (Rozwój sieci parafialnej w Toruniu od średniowiecza do czasów współczesnych) oraz członkowie ToMiTo: wiceprezes, historyk dr hab. Piotr Oliński, prof. UMK (Poczatki reformacji w Toruniu) i członek prezydium Towarzystwa, historyk sztuki dr hab. Piotr Birecki (Architektura $i$ sztuka ewangelicka $w$ Toruniu). Po wystąpieniach odbyła się promocja wydawnictw: pokonferencyjnego Toruń miasto wielu wyznań oraz dwutomowego W 500-lecie Reformacji. Z dziejów Kościołów Ewangelickich $w$ dawnych Prusach Królewskich i Ksiązęcych. Wydawnictwa zaprezentowali profesorowie: Jarosław Kłaczkow i Grzegorz Jasiński. Wydarzenie cieszyło 
się dużym zainteresowaniem publiczności, która wypełniła całą Salę Mieszczańską Ratusza Staromiejskiego w Toruniu. Toruńskie uroczystości zakończył koncert zespołu Śląsk w sali na Jordankach. Konferencję opisano także na blogu Działu Informacyjno-Bibliograficznego Książnicy Kopernikańskiej.

Dnia 5 grudnia 2017 r. w Domu Muz na Podgórzu odbyła się promocja wydawnictwa 460 lat Podgórza. W programie imprezy były m.in. odczyt „Dybów miasto zaginione” Piotra Wronieckiego oraz konkurs dla młodzieży szkolnej z cyklu „Czy znasz Toruń?”.

Popularyzacji wiedzy o Toruniu służyły organizowane przez Towarzystwo Miłośników Torunia i Książnicę Kopernikańską wykłady i prelekcje w ramach Wieczorów Toruńskich. Często towarzyszyły im również wystawy nawiązujące do tematyki spotkań. Odbyło się pięć wieczorów w Książnicy Kopernikańskiej przy ulicy Słowackiego 8:

- 23 listopada 2017 r. „Mennonici w okolicach Torunia w XVI-XX wieku" - dr Michał Targowski (260 uczestników; wraz z wystawą tematyczną ze zbiorów Książnicy Kopernikańskiej),

- 24 grudnia 2017 r. „Wokół »Gazety Toruńskiej« (1867-1921)”, spotkanie z okazji 150-lecia pierwszego polskiego dziennika na Pomorzu" z udziałem prof. dra hab. Szczepana Wierzchosławskiego i dra Tomasza Krzemińskiego z Instytutu Historii PAN (80 uczestników, wystawa ze zbiorów Książnicy Kopernikańskiej o rodzinie Buszczyńskich, toruńskich drukarzy i wydawców),

- 22 lutego 2018 r. ,»Nowości« w latach przełomu. Fakty, mity, imaginacje" - spotkanie z red. Andrzejem Szmakiem (80 uczestników; wraz z wystawą tematyczną ze zbiorów Książnicy Kopernikańskiej),

- 20 kwietnia 2018 r. „Dla szkoły i miasta. O bibliotece Gimnazjum Akademickiego słów kilka" - wykład prof. Iwony Imańskiej w ramach Toruńskiego Festiwalu Nauki (55 uczestników; wraz z wystawą tematyczną ze zbiorów Książnicy Kopernikańskiej „Skarby biblioteki Gimnazjum Akademickiego w Toruniu", której kustoszem była Anna Mazerska z Książnicy Kopernikańskiej),

- 24 maja 2018 r. „Urbanonimia Torunia a problem ochrony zabytków niematerialnego dziedzictwa kulturalnego" - wykład Artura Trapszyca (80 uczestników, impreza w trakcie Walnego Zebrania Towarzystwa).

Informacje o Wieczorach Toruńskich zamieszczano w „Ikarze”, toruńskim dzienniku „Nowości”, witrynie internetowej Książnicy Kopernikańskiej, stronach FB ToMiTo i Książnicy Kopernikańskiej. Zapowiedzi i relacje z Wieczorów ukazały się także w lokalnych wydaniach „Aktualności Toruńskich” TV Toruń oraz na blogu Działu Informacyjno-Bibliograficznego Książnicy 
Kopernikańskiej. Relacja z Wieczoru o mennonitach znalazła się także w „Zbliżeniach” TV Bydgoszcz w dniu imprezy.

Przeprowadzono cztery edycje konkursu wiedzy o Toruniu dla młodzieży szkolnej z cyklu „Czy znasz Toruń?”, nagrodzono 47 uczestników. Konkurs organizowany jest za pośrednictwem toruńskiego dziennika „Nowości”, a pytania konkursowe układał Krzysztof Kopiński. W roku 2017, we współpracy z Książnicą Kopernikańską w Toruniu, rozszerzyliśmy konkurs o grupę najmłodszych uczestników. Pytania zostały zamieszczone również na stronie internetowej Książnicy Kopernikańskiej oraz na FB ToMiTo i Książnicy. Ostatnia edycja specjalna miała charakter gry miejskiej i wystartowała pod tytułem „Zagadkowa Książnica”, a jej pytania i zadania związane były nie tylko z rocznicą i historią tej zacnej niegdyś miejskiej biblioteki, ale także z Mikołajem Kopernikiem (konkurs - gra miejska został opracowany i zorganizowany przez pracowników Książnicy: Agnieszkę Ignaszak, Aleksandrę Martini-Surman, Marcina Pejkowskiego, Emilię Raczkowską, Monikę Wróblewską, Magdalenę Zielińską). Rozstrzygnięcie zostanie opisane w sprawozdaniu w następnym roku, konkurs-gra trwał bowiem do 26 maja $2018 \mathrm{r}$.

W Roku Anny Wazówny, córki Jana III Wazy i Katarzyny Jagiellonki, zorganizowano nabożeństwo ekumeniczne w 450. rocznicę jej urodzin. Nabożeństwo zostało odprawione 17 maja $2018 \mathrm{r}$. o godz. $18.00 \mathrm{w}$ kościele Wniebowzięcia Najświętszej Marii Panny w Toruniu, gdzie księżniczka została pochowana w 1636 r. Jego organizatorami prócz Towarzystwa Miłośników Torunia były Parafia Wniebowzięcia Najświętszej Marii Panny, Parafia Ewangelicko-Augsburska w Toruniu oraz Książnica Kopernikańska w Toruniu. Liturgii przewodniczył ks. kanonik dr hab. Krzysztof Krzemiński (kierownik Referatu ds. Dialogu Religijnego Wydziału Duszpasterskiego Kurii Diecezjalnej Toruńskiej), a wraz z nim liturgię sprawowali ks. prałat proboszcz Parafii Wniebowzięcia Najświętszej Marii Panny Wojciech Niedźwiecki oraz ks. Michał Walukiewicz, proboszcz Parafii EwangelickoAugsburskiej w Toruniu, który wygłosił okolicznościową homilię. Po zakończeniu liturgii prezes Towarzystwa Miłośników Torunia K. Mikulski i dyrektor Książnicy Kopernikańskiej D. Ryszkowska-Mirowska złożyli w imieniu uczestników nabożeństwa wiązankę kwiatów przy sarkofagu księżniczki Anny Wazówny.

W dniu 25 października 2017 r. podpisaliśmy umowę o współpracy z Wojewódzką Biblioteką Publiczną - Książnicą Kopernikańską przy realizacji zadań z zakresu kultury, dzięki niej powrócono m.in. do wspólnej organizacji cyklu spotkań Wieczory Toruńskie. O wspólnych planach obu partnerów poinformowano media regionalne $\mathrm{w}$ trakcie konferencji prasowej, która odbyła się 
w siedzibie Książnicy Kopernikańskiej w dniu 20 listopada 2017 r. Relację z niej można było znaleźć we wszystkich mediach lokalnych.

W dniu 3 listopada 2017 r. podpisaliśmy list intencyjny - deklarację współpracy z powstającym przy Wydziale Sztuk Pięknych UMK w Toruniu Centrum Badań i Konserwacji Dziedzictwa Kulturowego.

Informacje o konkursach i spotkaniach organizowanych przez ToMiTo umieszczane były na łamach lokalnej prasy (głównie w toruńskim dzienniku „Nowości” i miejskim informatorze „Ikar”) oraz na stronie internetowej www.tomito.cba.pl, Książnicy Kopernikańskiej www.ksiaznica.torun.pl, na facebooku ToMiTo, profilu FB Książnicy Kopernikańskiej, na blogu Działu Informacyjno-Bibliograficznego Książnicy Kopernikańskiej, który prowadzi Grzegorz Barecki ${ }^{1}$, a także w formie krótkiej notatki i linku na stronach Towarzystwa Bibliofilów im. Joachima Lelewela w Toruniu http://www.bibliofile. torun.pl/joomla/ (tam zamieszczała je dr hab. Wanda Ciszewska, członek TBL oraz Rady Naukowej Książnicy Kopernikańskiej). Media lokalne zapowiadały i relacjonowały wydarzenia ToMiTo i Książnicy Kopernikańskiej, informacje te podawano także w programie red. Ewy Jarczyk „Bulwar Sztuki” (który jest wydawany jako program TV Torun, ale ma też swe wydanie internetowe).

Towarzystwo wspomagało prace stacji krótkofalarskiej promującej wydarzenia i miasto Toruń oraz region toruński wśród kilkuset nadawców i nasłuchowców w kraju i za granicą w czasie pracy stacji Klubu Krótkofalowców Polskiego Związku Krótkofalowców FORT IV przy ToMiTo. Szczególne zainteresowanie wzbudziła działalność stacji okolicznościowej SN20WHL w grudniu 2017 r. nawiązująca do dwudziestej rocznicy wpisania toruńskiego średniowiecznego zespołu miejskiego na Listę Światowego Dziedzictwa Kulturowego UNESCO (World Heritage List - w skrócie WHL w sufiksie znaku okolicznościowego).

W dniu 14 grudnia 2017 r. powstał trzyosobowy Komitet Odbudowy Pomnika Wojsk Balonowych, jego przewodniczącym został red. Andrzej Szmak, a członkami Michał Targowski i Mariusz Thomas. Komitet rozpoczął działal-

\footnotetext{
${ }^{1}$ Blog „Informatorium” jest witryną internetową Działu Informacyjno-Bibliograficznego Wojewódzkiej Biblioteki Publicznej - Książnicy Kopernikańskiej w Toruniu; działa od marca 2011 r.; jego wpisy przyciągają co miesiąc około 2700 odwiedzających. Ważną kategorią wpisów na blogu są relacje z wydarzeń kulturalnych, jakie odbywają się w Książnicy. Wśród nich wyróżniają się zwłaszcza reaktywowane Wieczory Toruńskie organizowane przez Towarzystwo Miłośników Torunia. Na blogu znajdują się relacje $\mathrm{z}$ Wieczorów Toruńskich, podkreślana jest wysoka frekwencja, atrakcyjna tematyka, profesjonalne przygotowanie prelegentów, którymi są najwybitniejsi mieszkańcy Torunia.
} 
ność podczas uroczystej konferencji prasowej poświęconej inicjatywie ToMiTo dotyczącej rekonstrukcji pomnika wojsk balonowych w parku na Bydgoskim Przedmieściu. Na potrzeby promocji została wykonana makieta pomni$\mathrm{ka}$, zaprezentowano ją $\mathrm{w}$ trakcie konferencji. Rozpoczęto także zbiórkę na rzecz odbudowy pomnika, do końca kwietnia 2018 r. zebrano kwotę 5284,94 zł.

Przewodnikiem Roku 2016 została Magdalena Łubieńska, uroczyste wręczenie wyróżnienia nastąpiło na Walnym Zebraniu w dniu 25 maja 2017 r., a Przewodnikiem Roku 2017 został Jarosław Filejski.

\section{Wydawanie publikacji związanych z dziejami Torunia}

W okresie sprawozdawczym Towarzystwo opublikowało z pomocą finansową Gminy Miasta Toruń następujące wydawnictwa:

- 44 tom „Rocznika Toruńskiego”, pod redakcją Agnieszki Zielińskiej, wydawany w porozumieniu z UMK,

- Toruń miasto wielu wyznań, pod redakcją Jarosława Kłaczkowa, Piotra Olińskiego, Waldemara Rozynkowskiego, zbiór materiałów z konferencji w 500. rocznicę reformacji,

- 460 lat Podgórza 1555-2015, pod redakcją Krzysztofa Mikulskiego, druk w porozumieniu z Drukarnią TOTEM; nakład wznowiono, cieszył się dużym powodzeniem,

- Georg Vick - toruński złotnik pierwszej połowy XVIII wieku, autor: Bartłomiej Łyczak,

- kolorowy okolicznościowy folder, przygotowany przez Arkadiusza Kierysa $\mathrm{z}$ okazji kwesty na cmentarzu w dniu 1 listopada, wydany wspólnie z Urzędem Miasta Torunia.

Do 8 tomu Toruńskiego Słownika Biograficznego przyjęto 40 opracowanych haseł biogramów.

Wszystkie wydawnictwa Towarzystwa znalazły się w sprzedaży na VI Kiermaszu Książki Regionalnej, który odbył się 14 maja 2018 r. w Bibliotece Uniwersyteckiej w Toruniu.

Promocja „Rocznika Toruńskiego” i innych wydawnictw ToMiTo, w tym 460 lat Podgórza 1555-2015, odbyła się 23 stycznia 2018 r. w Książnicy Kopernikańskiej, imprezie towarzyszyła wystawa poświęcona Tadeuszowi Zakrzewskiemu „,Dedykacje książkowe Tadeusza Zakrzewskiego (1922-2014) ze zbiorów żony - Anny Zakrzewskiej - niegdyś bibliotekarki Książnicy Miejskiej w Toruniu" - wydarzenie cieszyło się wyjątkowo dużym zainteresowaniem, odnotowano także rekordową sprzedaż wydawnictw. 
$\mathrm{Na}$ zakończenie sprawozdania $\mathrm{z}$ działalności Towarzystwa Miłośników Torunia pragniemy podziękować za pomoc udzieloną nam przez liczne instytucje: władze miasta Torunia z prezydentem Michałem Zaleskim i przewodniczącym Rady Miasta Marcinem Czyżniewskim, Uniwersytet Mikołaja Kopernika z rektorem prof. dr. hab. Andrzejem Tretynem, Wojewódzką Bibliotekę Publiczną - Książnicę Kopernikańską z dyrektor Danettą RyszkowskąMirowską, Muzeum Okręgowe z dyrektorem dr. Markiem Rubnikowiczem, Biuro Miejskiego Konserwatora Zabytków z dyrektorem Emanuelem Okoniem, Muzeum Etnograficzne im. im. Marii Znamierowskiej-Prüfferowej, Fundację „Zamek Dybów i Gród Nieszawa”, Fundację Generał Elżbiety Zawackiej, Wydawnictwo Adam Marszałek, Drukarnię TOTEM, Drukarnię Machina Druku, Dom Muz, Archiwum Państwowe w Toruniu, PTTK - Oddział Przewodnicki, Naczelną Organizację Techniczną, Towarzystwo Bibliofilów im. J. Lelewela w Toruniu oraz redakcję „Nowości”. Niezawodną pomoc w czasie organizowania konkursu „Toruń w kwiatach” okazywały nam firmy „Patio” i „Skwer”. Nasze podziękowania pragniemy również przekazać wszystkim osobom, które w dniu 1 listopada cierpliwie krążyły po cmentarnych dróżkach, zbierając datki przekazywane na renowację zniszczonych nagrobków, a wszystkim ofiarodawcom pięknie dziękujemy. 


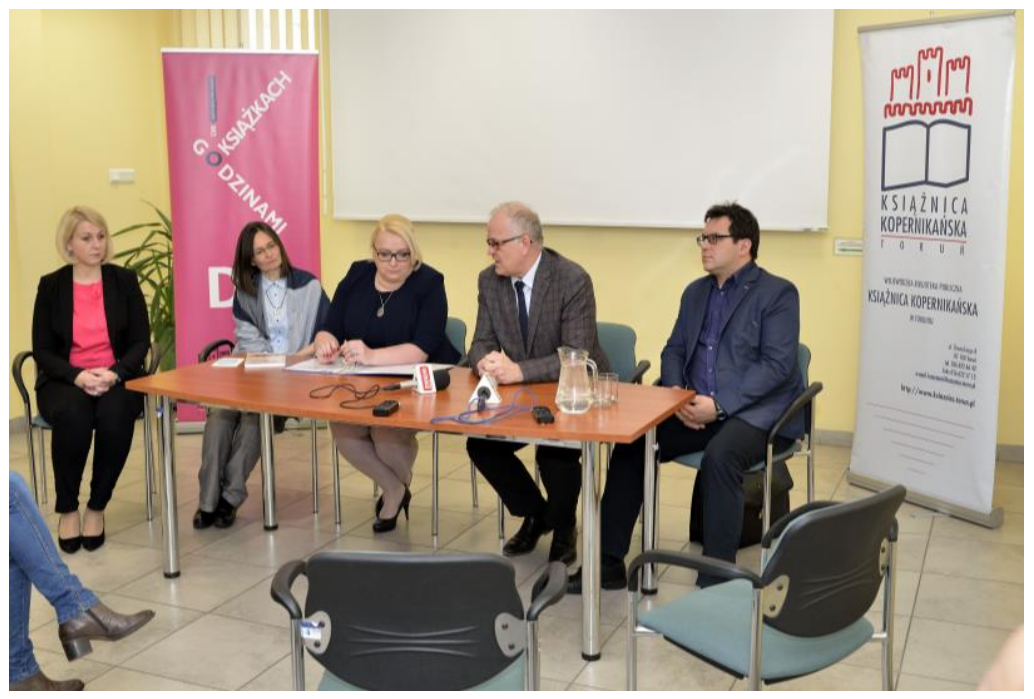

Konferencja prasowa Towarzystwa Miłośników Torunia i Książnicy Kopernikańskiej, 20 listopada 2017 r., fot. T. Dorawa

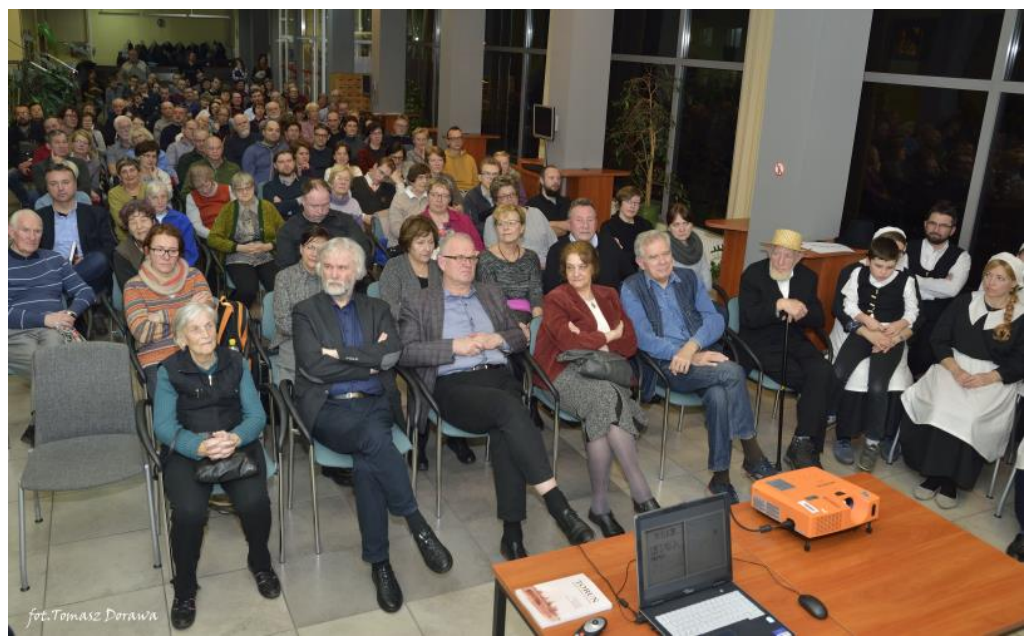

Wieczór Toruński - 23 listopada 2017 r. „Mennonici w okolicach Torunia w XVI-XX wieku”, fot. T. Dorawa 


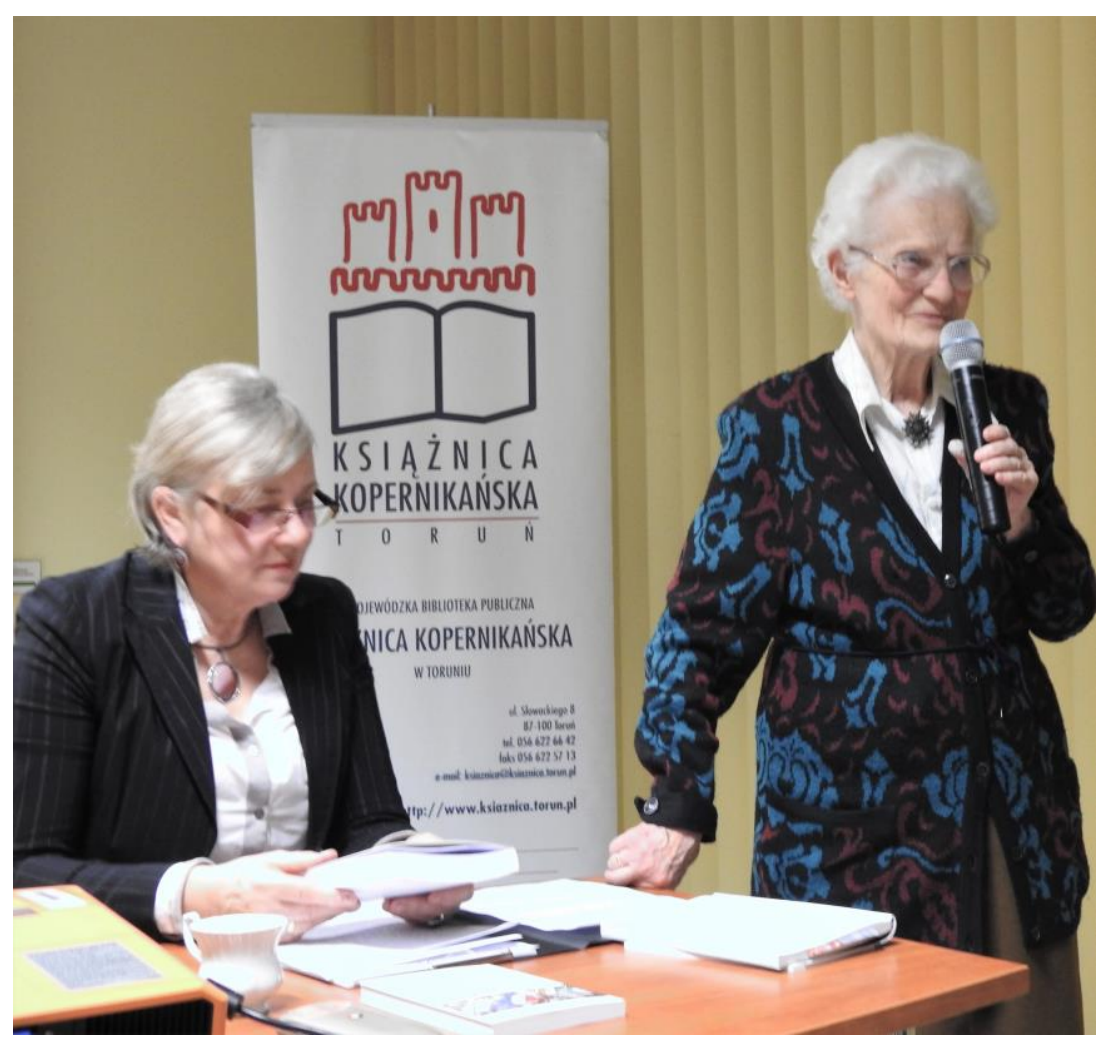

Promocja wydawnictw Towarzystwa Miłośników Torunia - 23 stycznia 2018 r., Cecylia Iwaniszewska (z prawej) oraz Jolanta Wasiewska, fot. K. Tomkowiak 


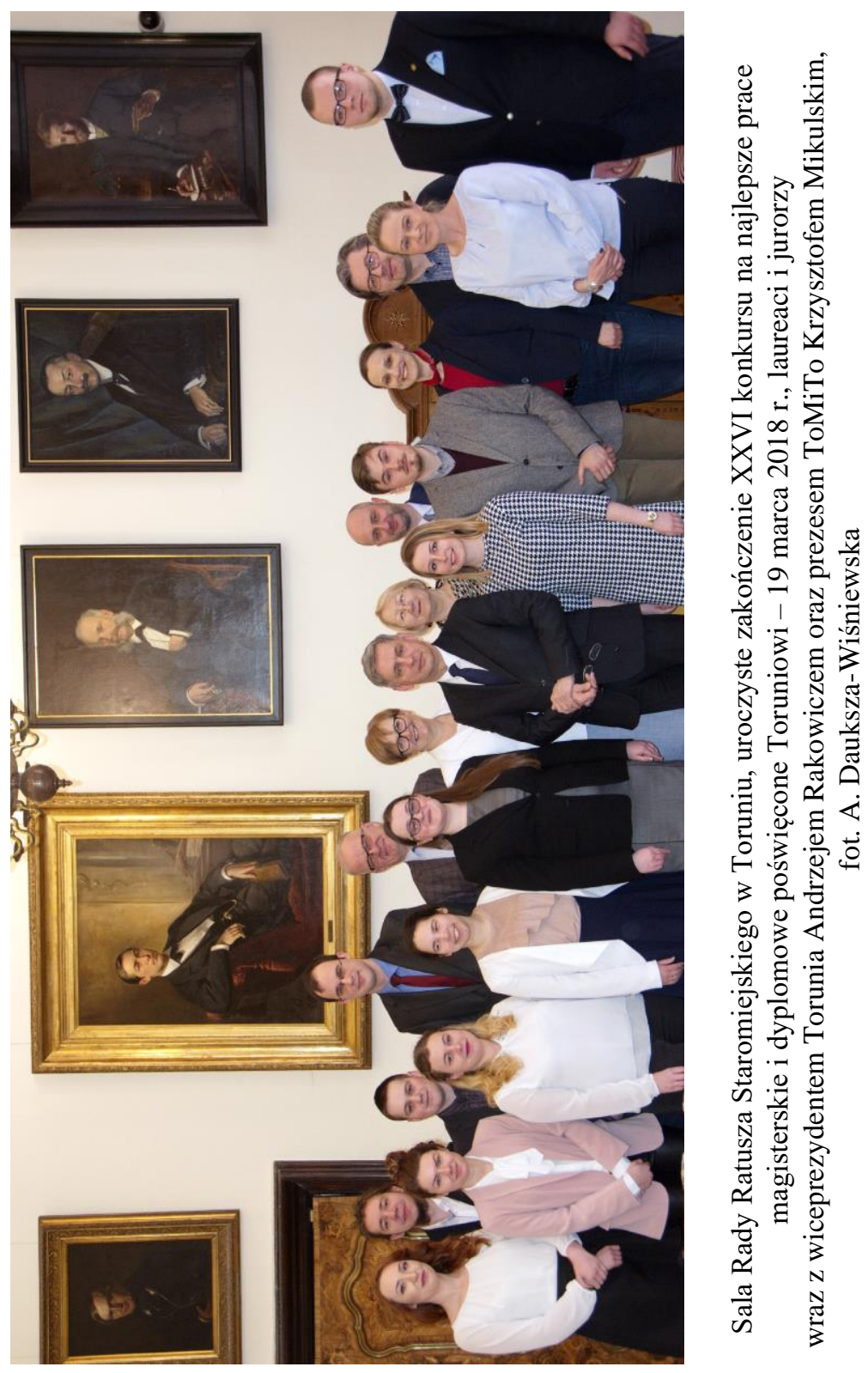

310 


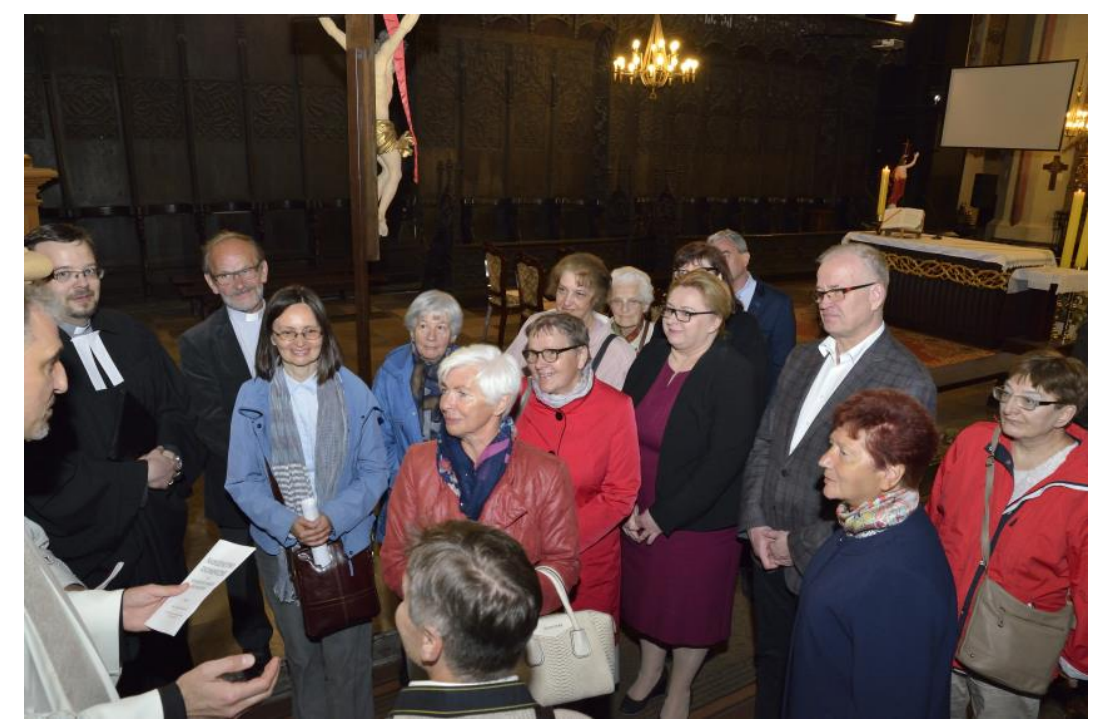

Uczestnicy nabożeństwa ekumenicznego, które odbyło się w 450. rocznicę urodzin Anny Wazówny 17 maja 2018 r. w kościele Wniebowzięcia Najświętszej Marii Panny w Toruniu, gdzie księżniczka została pochowana w 1636 r., fot. A. Dorawa 


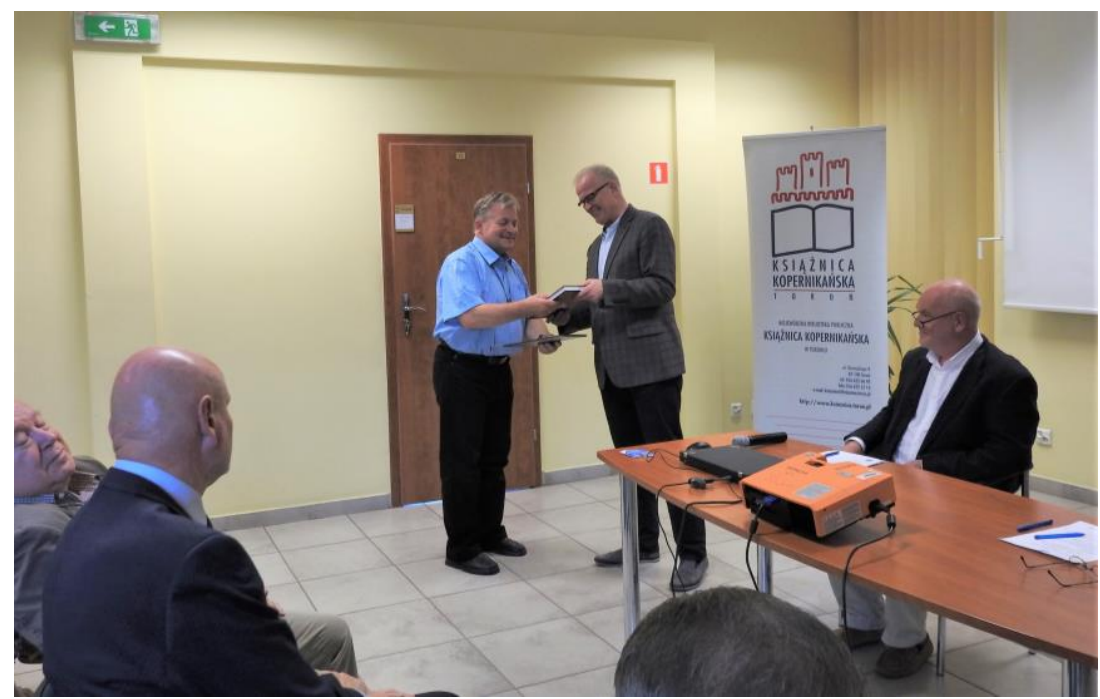

Walne Zebranie ToMiTo 24 maja 2018 r. Prezes Krzysztof Mikulski wręcza nagrodę Przewodnikowi Roku 2017 Jarosławowi Filejskiemu, fot. K. Tomkowiak 